\title{
Japanese Poems with Strong Nature Themes as a Tool for Environmental Education
}

\author{
Deborah H. Williams ${ }^{1,2}$, Gerhard P. Shipley³ \\ ${ }^{1}$ Department of Environmental Science, Johnson County Community College, Overland Park, KS, USA \\ ${ }^{2}$ Department of Anthropology, University of Kansas, Lawrence, KS, USA \\ ${ }^{3}$ University of Kansas, Lawrence, KS, USA \\ Email: Research_Studies@outlook.com
}

How to cite this paper: Williams, D. H., \& Shipley, G. P. (2019). Japanese Poems with Strong Nature Themes as a Tool for Environmental Education. Creative Education, 10, 2457-2472.

https://doi.org/10.4236/ce.2019.1011174

Received: November 15, 2019

Accepted: November 18, 2019

Published: November 21, 2019

Copyright $\odot 2019$ by author(s) and Scientific Research Publishing Inc. This work is licensed under the Creative Commons Attribution International License (CC BY 4.0).

http://creativecommons.org/licenses/by/4.0/

(c) (i) Open Access

\begin{abstract}
Traditional Japanese poems with strong nature themes are still very relevant today as relatable statements of environmental consciousness and the value and appreciation of nature, and can be a useful tool for environmental education. This paper is a brief study of various aspects and elements of these poems, particularly the related aesthetic and philosophical perspectives of wabi-sabi and Zen Buddhism and the importance of nature and season, with the goal of developing greater appreciation for their relevance and communicative power. To illustrate these concepts, related but otherwise independent poems are presented in several coherent groupings and analyzed with regard to wabi-sabi/Zen terms, season terms, and additional nature terms. Wabi-sabi is one of the core concepts and defining perspectives of Japanese culture, has its roots in the Zen perspective, and exemplifies many of the core tenets of Zen. The wabi-sabi and Zen perspectives in Japanese poetry with particularly strong environmental themes provide a vehicle for environmental communication with great emotive power. National and international government agencies, non-governmental organizations, and institutions of higher education have all created or hosted online haiku pages to facilitate their environmental education missions. In particular, the universal appeal, timelessness, and nature-focus of the wabi-sabi and Zen perspectives contribute to the continued relevance of these poems to developing environmental awareness and addressing contemporary concerns about the environment, including the intractable problem of climate change, the solution to which is unlikely to be found in the same technoscientific paradigm that created it.
\end{abstract}

\section{Keywords}

Haiku, Wabi-Sabi, Zen, Environmental Education, Climate Change 


\section{Introduction}

Traditional Japanese poems with strong nature themes are still very relevant today as relatable statements of environmental consciousness and the value and appreciation of nature, and can be a useful tool for environmental education. Haiku, in particular, is one of the most familiar forms of verse and is primarily understood to be a sketch of nature shasei ("sketch of nature") (Barnhill, 2004). Efforts to employ haiku in environmental education began at least in the early 1970s (see, e.g. Kundell, 1973), but these generally were very short articles providing little or none of the necessary historical and cultural knowledge to fully appreciate the great depth and potential usefulness of Japanese poetry. Unfortunately, to many Westerners haiku are simply very short poems characterized by a rigid adherence to a particular syllabic scheme.

This paper therefore begins with a brief study of various aspects and elements of these poems, particularly the related aesthetic and philosophical perspectives of wabi-sabi and Zen Buddhism, the importance of season, and additional nature terms, with the goal of developing greater appreciation for and understanding of the poems. Having established this essential background, the remainder of the paper presents several coherent groupings of related but otherwise independent poems and analyzes them with regard to these aspects and elements. The universal appeal, timelessness, and nature-focus of these perspectives contribute to the continued relevance of Japanese poems to environmental education, including broadly developing environmental awareness in both informal and formal educational contexts, and to addressing contemporary concerns about the environment.

\section{Wabi-Sabi}

Wabi-sabi is one of the core concepts and defining perspectives of Japanese culture (Koren, 2008). "Wabi-sabi is the most conspicuous and characteristic feature of what we think of as traditional Japanese beauty... Wabi-sabi can in its fullest expression be a way of life. At the very least, it is a particular type of beauty" (Koren, 2008: p. 21). It is both an aesthetic and a philosophy rooted in the acceptance of inevitability, the truth-value of nature (impermanence, imperfection, incompleteness), and the beauty of ugliness (Koren, 2008). Despite its importance in Japanese culture, wabi-sabi is difficult to define, and mystery and elusiveness are part of its aesthetic such that "to fully explain the concept might, in fact, diminish it" (Koren, 2008: p. 18).

Wabi is concerned with simplicity (Teiji, Ikko, \& Tsune, 1993) and reflected in rusticity (Richie, 2007), and is the more philosophical concept (Richie, 2007; Koren, 2008). Wabi has been described as containing notes of transient natural beauty and poverty (Barnhill, 2004). Sabi is concerned with time and its effects (Richie, 2007) and is reflected in the patina of age (Teiji, Ikko, \& Tsune, 1993), and is the more aesthetic concept (Richie, 2007; Koren, 2008). Sabi has been described as containing notes of loneliness, melancholy, sorrow, stillness, and tran- 
quility (Barnhill, 2004; Richie, 2007). However, the independent concepts of wa$b i$ and $s a b i$ have developed so many connotations and interpretations that for almost all purposes they can be used interchangeably and together (Juniper, 2003; Koren, 2015).

Koren (2008) characterized wabi-sabi as present-oriented, romanticizing nature, comfortable with ambiguity and contradiction, generally dark, unconcerned with function and utility, and seasonal. Koren (2008) contrasted the Western modern aesthetic with the Japanese wabi-sabi aesthetic as being, respectively, enriched by purity versus enriched by corrosion; intolerant of ambiguity versus comfortable with ambiguity; maintained versus worn; slick versus crude; romanticizing technology versus romanticizing nature; having faith in progress versus denying progress; mass-produced versus unique; and everlasting versus decaying.

\section{Zen Buddhism}

Wabi-sabi has its roots in the Zen perspective and exemplifies many of the core tenets of Zen (Suzuki, 1959; Juniper, 2003; Koren, 2008: p. 15, referring to wabi-sabi as the "Zen of things"). Juniper (2003: p. ix, p. 1, p. 11) made a particularly direct connection between wabi-sabi and Zen:

As the artistic mouthpiece of the Zen movement, wabi-sabi art embodies the lives of the monks and is built on the precepts of simplicity, humility, restraint, naturalness, joy, and melancholy as well as the defining element of impermanence... Wabi-sabi embodies the Zen nihilistic cosmic view and seeks beauty in the imperfections found as all things...evolve from nothing and devolve back to nothing... Wabi-sabi reflects the Buddhist emphasis on impermanence and continuous change, and so Zen monks strove to produce or find objects and environments that embodied wabi-sabi as aids toward spiritual enlightenment.

Traditionally, Zen was present in most aspects of the cultural life of the Japanese people (Suzuki, 1959). In Zen, satori (“enlightenment") is found not in ritual, dogma, or texts but in personal experience through lived perceptions, psychological processes, and mental states, i.e. "the path of enlightenment is natural" (Cleary, 1998: pp. xiii-xiv, quoting Lung-ya (834-920); see also Suzuki, 1964: p. 33, noting that "Personal experience is everything in Zen"). Suzuki (1964) characterized Zen as rejecting the ordinary process of reason as insufficient and ultimately incapable of providing enlightenment, and therefore requiring the development of an entirely new perspective with which to examine and understand the mysteries of life and the secrets of nature. Until this perspective is fully realized and enlightenment is achieved, we are subject to samsara (the continuous cycle of death and rebirth), struggle and failure, and the suffering that entails (Suzuki, 1960). In contrast to the West's emphasis on man separated from and in competition with nature, Zen emphasizes intimacy and harmony: 
In engaging Zen training with an eye on its relationship to ecological concerns, we ask the question, "Where does the Earth end and where do I begin?... The whole point of Zen training in a natural environment is to make us open and receptive to...nature itself as the teacher" (Loori, 2007: p. 3, p. 12).

\section{Japanese Poetry}

Early forms of Japanese waka ("poetry") included the choka ("long poem") which had an indefinite number of lines with a repeating syllabic pattern of 5-7, and the tanka ("short poem") which had a more limited form of 31 syllables over 5 lines, with a syllabic pattern of 5-7-5-7-7 (Hoffman, 1996). Until the sixteenth century, nearly all Japanese poems were tanka (Hoffman, 1996). Haikai no renga ("popular linked verse") was created by dividing tanka into two components with syllabic patterns of 5-7-5 and 7-7 (Hoffman, 1996; Barnhill, 2004). The hokku ("opening phrase") or first stanza of a renga poem was considered particularly important in establishing the setting, including the season, for the entire poem (Blyth, 1949; Higginson, 1996; Barnhill, 2004). Because the hokku was a complete statement in itself, renga poets such as Matsuo Basho, who is perhaps the most renowned Japanese poet, began creating semi-independent hokku that could be appreciated by themselves (Hoffman, 1996; Barnhill, 2004). So strictly speaking, Basho was a hokku poet (Higginson, 1996; Hoffman, 1996; Barnhill, 2004; Takiguchi, 2005). The relatively recent haiku is a fully independent hokku created to stand alone (Higginson, 1996; Barnhill, 2004).

Although haiku may be more familiar to non-Japanese, tanka are also historically and culturally influential and often nature-oriented. Most tanka contain two poetic images: The first is taken from nature, and the second is a meditative complement to the nature image (Hoffman, 1996). "The tanka poet may be likened to a person holding two mirrors in his hand, one reflecting a scene from nature, the other reflecting himself as he holds the first mirror. The tanka thus provides a look at nature, but it regards the observer of nature as well" (Hoffman, 1996: pp. 19-20).

According to Suzuki (1959), haiku embodies the Japanese character: Concise, non-argumentative, factual, and stoic. Haiku evokes only one essentially descriptive poetic image which aims at significance, not entertainment, because it shows us what we already know but to which we simply fail to attend (Blyth, 1949; Hoffman, 1996). Three general conventions apply to haiku: 1) it describes a single state or event, 2) it is set in the present, and 3) it refers to or concerns a particular season (Hoffman, 1996). The most successful haiku are written in the "haiku moment", a state in which distinctions between subject and object, self and other become blurred (Hoffman, 1996). This is the Zen state of satori, i.e. the understanding or enlightenment which is a first step toward awakening. "Haiku is the expression of temporary enlightenment," as the creative impulse of the master poet is nothing less than the flash of satori (Suzuki, 1959: pp. 220-221, p. 228, 
Table 1. Example Translations of Basho's "Old Pond."

\begin{tabular}{|c|c|c|c|c|}
\hline Original & Cohen (1972: p. 46) & Hamill \& Seaton (2004: p. 149) & Addiss (2012: p. 12) & Takiguchi (2005: citing Nobuyuki Yuasa) \\
\hline $\begin{array}{l}\text { Furu ike ya } \\
\text { kawazu tobikomu } \\
\text { mizu no oto }\end{array}$ & $\begin{array}{l}\text { Mossy pond; } \\
\text { frog leaping in- } \\
\text { splash! }\end{array}$ & $\begin{array}{l}\text { At the ancient pond } \\
\text { a frog plunges into } \\
\text { the sound of water. }\end{array}$ & $\begin{array}{l}\text { Old Pond- } \\
\text { a frog jumps in } \\
\text { the sound of water. }\end{array}$ & $\begin{array}{l}\text { Breaking the silence } \\
\text { of an ancient pond, } \\
\text { a frog jumped into } \\
\text { water- } \\
\text { a deep resonance. }\end{array}$ \\
\hline
\end{tabular}

quoting R. H. Blyth). In this Zen state of "no mind", the author does not force his mind upon the scene but rather effortlessly sees the world as it is, and as a result, the poem captures an "eternal now" (Zheng, 2014). Thus, haiku are to be created, understood, and appreciated from the Zen point of view (Blyth, 1949). "When you begin to think, you miss the point [of Zen]", and when you attempt to intellectualize haiku, you destroy its truth and beauty (Suzuki, 1959: p. 13, quoting Zen master Tenno Dogo (748-807); see also Hamill \& Seaton, 2004: p. 1, noting that "Zen is a matter of character, not a matter of intellect").

As Robert Frost famously said, "poetry is what gets lost in translation". English translations of Japanese poetry, particularly haiku, are often inaccurate, and different translations can convey very different impressions (Hoffman, 1996; Barnhill, 2004). Given the extremely concise nature of haiku, translators are often tempted to make explicit or specific what is implicit or ambiguous or to clarify symbols or associations. For example, according to Takiguchi (2005) there are more than 170 different English translations of Basho's famous "old pond" poem, a few of which are shown in Table 1 to illustrate some of the many differences and their effects on how the poem may be received by the reader.

The problem of faithfully translating Japanese poetry is exacerbated by a tension between translating them literally and translating them to include at least some of the embedded meaning. "To read properly a single haiku requires years of unconscious absorption of all of the culture of India, China, and Japan that comes to fulfillment in these small verses" (Blyth, 1949: p. vi). Japanese poetry is full of symbolism and associations, and understanding them is essential to fully appreciating it (Barnhill, 2004). The famously concise haiku are particularly rich with additional information that non-Japanese readers often miss. Examples of commonly used symbols and associations include the pine, crane, and tortoise representing longevity; the lightning, dew, and hibiscus representing impermanence; the chrysanthemum representing purity and aristocracy; and the moon representing enlightenment (Barnhill, 2004; Takashina \& Treyvaud, 2018).

\section{Nature and Seasonality}

According to Takashina and Treyvaud (2018), the Japanese aesthetic is less concerned with identifying the beauty of things and more concerned with identifying the beauty of situations. Basho in particular found beauty in "the world of deep silence, pregnant with tension... That beauty had no physical form; it was 
purely situational" (Takashina \& Treyvaud, 2018: p. 175). Situational beauty, like the spring dawn or autumn evening, is fleetingly transient. The Zen focus on the transience of existence was embodied in images of the changing of the seasons (Hoffman, 1996). "To the Japanese, beauty is inextricably linked to the change of seasons and the passage of time-in short, to the workings of nature" (Takashina \& Treyvaud, 2018: p. 176). "Even today the Japanese share a deep identification with nature... Nature bursting with vitality, appearing and disappearing in cycles of life and death, or summer and winter, spring and fall" (Hoffman, 1996: pp. 38-39). Hoffman (1996: p. 39) characterized the Japanese relationship with nature as "no mere gesture of aesthetic appreciation, but an act of worship". The kigo, which is a word, symbol, or association which identifies the season is "a trigger which releases a whole world of emotion, of sounds and scents and colors" (Blyth, 1949: p. 382). Some early Japanese anthologies of poems, such as Kokinshū and Man'yoshü, even organized poems by their seasons (Takashina \& Treyvaud, 2018).

The season may be identified by such symbols or associations as the temperature, length of day, and weather; changes in the land; festivals and other seasonal events; and seasonal behaviors of plants (e.g. blooming flowers, falling leaves), animals (e.g. nesting birds, migrating birds), and men (e.g. planting, harvesting) (Blyth, 1949). Ubiquitous natural phenomenon may be modified to evoke different seasons, such as warm rain or wind versus cold rain or wind, wet grass versus withered grass, and new blossoms versus falling leaves. More broadly, spring is associated with newness, beginnings, youth, and life, while winter is associated with age, endings, and death. Table 2 presents a sampling from Barnhill (2004) and Higginson (1996) of common seasonal identifiers used in Japanese poetry.

The significance of some kigo may be cultural, geographical, or historical and so may be difficult for non-Japanese to appreciate without some research. For example, a "fulling block" was a wooden tool used to pound clothing and bedding and thereby soften and impart a sheen to the fabric, and its sound was considered melancholic and associated with autumn (Barnhill, 2004; Greve, 2017). For another example, "cats in love" refers to the fact that cats mate in earnest from mid-winter through early spring during which time male cats may emit loud wails in their search for females (Higginson, 1996; Greve, 2017).

\section{Methods}

We reviewed hundreds of Japanese poems and selected a number of examples based on their strong environmental themes and their ability to demonstrate the concepts discussed above. In Tables 3-8, these poems are analyzed with respect to wabi-sabi/Zen terms, kigo, and additional nature terms. Further, these otherwise independent poems are grouped both to provide the non-Japanese reader more content to consider, to further illustrate the concepts, and to achieve greater educational impact. For example, the first grouping below contains four otherwise 
independent poems by Basho which are related by their references to birds and by their progression through the four seasons.

Table 2. Example seasonal identifiers used in Japanese poetry.

\begin{tabular}{|c|c|c|c|}
\hline Spring & Summer & Autumn & Winter \\
\hline \multicolumn{4}{|c|}{ Weather, Astronomical, \& Related Misc } \\
\hline Haze & Ice house & Autumn wind & Banked charcoal \\
\hline Melting & Planting & Cool shade & Bedcovering \\
\hline \multirow[t]{9}{*}{ Nest } & Summer rain & Dew & Brazier \\
\hline & & Fan & Frost \\
\hline & & Fulling block & Frozen \\
\hline & & Lightning & Hail \\
\hline & & Mist & Snow \\
\hline & & Moon & Sunken hearth \\
\hline & & (inc. crescent, harvest) & Withered \\
\hline & & Moonlight & (inc. branch, field, grass) \\
\hline & & Windstorm & \\
\hline \multicolumn{4}{|c|}{$\underline{\text { Plants }}$} \\
\hline Azalea & Barley & Banana & Onion \\
\hline Blossoms & Eggplant & Chestnut & Radish \\
\hline (esp. cherry) & Green leaf & Chrysanthemum & Winter greens \\
\hline Peach & Hydrangea & Falling leaf & Winter melon \\
\hline Plum & Iris & Gourd & Winter peony \\
\hline Violet & Melon & Hibiscus & \\
\hline Willow & Peony & Ivy & \\
\hline \multirow[t]{6}{*}{ Wisteria } & Poppy & Millet & \\
\hline & Rice sprout & Morning glory & \\
\hline & Wheat & Mushroom & \\
\hline & Green leaf & Orchid & \\
\hline & Hydrangea & Red pepper & \\
\hline & & Reed & \\
\hline \multicolumn{4}{|c|}{$\underline{\text { Animals }}$} \\
\hline Barn swallow & Butterfly & Cricket & Blowfish \\
\hline Butterfly & Deer horn & Deer & Dried salmon \\
\hline Cats in love & Cuckoo & Dragonfly & Duck \\
\hline Departing goose & Firefly & Goose & Hawk \\
\hline Flies & Flea & Gray starling & Plover \\
\hline Frog & Mosquito & Quail & Whitefish \\
\hline
\end{tabular}


Continued

\begin{tabular}{cccc}
\hline $\begin{array}{c}\text { Pheasant } \\
\text { Skylark }\end{array}$ & Toad & Snipe & \\
Whitefish & Cicada & & \\
Young sparrow & & & \\
\hline \multicolumn{4}{c}{ Activities } \\
Blossom viewing & Bamboo planting day & Harvest & House cleaning \\
& Rice planting & Hulling rice & Rice-cake making \\
& Swimming & Moon viewing & Snow viewing \\
& Sweating & Washing potatoes & Year's end party \\
\hline Festival of the Otter & Summer airing & Festival of the dead & Festival of Ebisu \\
New Year's day & & Ritual of renewal & Year's end \\
Water-drawing rite & & Star festival & \\
\hline
\end{tabular}

\section{Results}

A first group of poems, all by Basho, is presented in Table 3. Basho (1644-1694) was a poet and lay Zen monk, and his work strongly reflects both wabi-sabi and Zen (Barnhill, 2004). "Basho, when asked for his advice to poets, said simply, 'Cultivate a mind to follow nature and return to nature"” (Murphy, 2014: p. 230).

Of course, the categorizations of some of these terms are somewhat subjective. Certain kigo terms, such as "spring", "autumn", and "winter" which can be stand-ins for the transient youth, peak, decline, and death stages of life, could also be categorized as wabi-sabi/Zen terms. However, when a term is clearly used as a kigo term, it has been preferentially categorized as such. Further, there is a great deal of overlap between wabi-sabi and Zen, as discussed above, so they have been presented as a single category to avoid arguments about how best to categorize any particular term. However, in a few cases, a term more clearly belongs to one than the other, and so it is important to note that the category of wabi-sabi/Zen should be understood as containing terms which are either wabi-sabi or Zen or both. For example, the term "nesting" evokes birth, and "nest" is a kigo for spring which is associated with beginnings, and so implicates the birth/beginning/renewal stage of samsara and is therefore more arguably a Zen term than a wabi-sabi term. This issue can also be seen in Basho's "old pond" poem in which the term "old pond" invokes both wabi-sabi and Zen, while the term "frog" more strongly invokes Zen ("frog" being a kigo term for spring which, like "nesting", evokes birth/beginning/renewal). The point of categorizing these terms is merely to show the reader that they can be categorized to better understand and appreciate the poems, not to over-intellectualize the issue.

Poems by Ryokan and Saigyo are presented in Table 4, and are related by their natural settings and activities involving mountains, water, and gathering. Ryokan (1758-1831) was a Japanese Zen monk well-known for his calligraphy 
Table 3. Selected Poems by Basho.

\begin{tabular}{|c|c|c|c|}
\hline Poem & Wabi-SabilZen Terms & Kigo & Additional Nature Terms \\
\hline $\begin{array}{l}\text { Nesting storks: } \\
\text { viewed through branches } \\
\text { of blossoms. } \\
\text {-Basho } \\
\text { (Barnhill, 2004: p. 57) }\end{array}$ & Nesting & $\begin{array}{l}\text { Storks; } \\
\text { blossoms } \\
\text { [spring] }\end{array}$ & Branches \\
\hline $\begin{array}{l}\text { In summer rains } \\
\text { the crane's legs } \\
\text { become short. } \\
\text {-Basho } \\
\text { (Barnhill, 2004: p. 28) }\end{array}$ & & $\begin{array}{l}\text { Summer; } \\
\text { crane }\end{array}$ & Rains \\
\hline $\begin{array}{l}\text { On a withered branch } \\
\text { a crow has settled- } \\
\text { autumn evening. } \\
\text {-Basho } \\
\text { (Barnhill, 2004: p. 25) }\end{array}$ & $\begin{array}{l}\text { Withered; } \\
\text { crow; } \\
\text { evening }\end{array}$ & Autumn & Branch \\
\hline $\begin{array}{l}\text { The sea darkening, } \\
\text { a wild duck's call } \\
\text { faintly white. } \\
\text {-Basho } \\
\text { (Barnhill, 2004: p. 47) }\end{array}$ & $\begin{array}{l}\text { Darkening; } \\
\text { faintly; } \\
\text { white }\end{array}$ & $\begin{array}{l}\text { Wild duck } \\
\text { [winter] }\end{array}$ & Sea \\
\hline
\end{tabular}

Table 4. Selected Poems by Ryokan and Saigyo.

\begin{tabular}{|c|c|c|c|}
\hline Poems & Wabi-Sabi/Zen Terms & Kigo & Additional Nature Terms \\
\hline $\begin{array}{l}\text { A single path through a dense forest, } \\
\text { mountains peek out from between the floating mist. } \\
\text { Not yet autumn, the leaves have already disappeared, } \\
\text { and without rain the rocks are always dark. } \\
\text { I gather tree mushrooms in a basket } \\
\text { and draw spring water into a jar. } \\
\text { Except for the stray traveler } \\
\text { no none finds their way here. } \\
\text { - Ryokan } \\
\text { (Maloney \& Oshiro, 1992) }\end{array}$ & $\begin{array}{l}\text { Single path; } \\
\text { disappeared; } \\
\text { dark; } \\
\text { "except for the stray traveler, no } \\
\text { one finds their way here" }\end{array}$ & "Not yet autumn" & $\begin{array}{l}\text { Dense forest; } \\
\text { mountains; } \\
\text { floating mist; } \\
\text { leaves; } \\
\text { rain; } \\
\text { rocks; } \\
\text { tree mushrooms; } \\
\text { spring water }\end{array}$ \\
\hline $\begin{array}{l}\text { Deep in the mountains, } \\
\text { Water splashes down the crags. } \\
\text { If I could stop it, } \\
\text { I'd go in search of wild nuts } \\
\text { that fall this time of year. } \\
\text {-Saigyo } \\
\text { (Hamill \& Seaton, 2004: p. 108) }\end{array}$ & $\begin{array}{l}\text { Deep; } \\
\text { "that fall this time of year" }\end{array}$ & $\begin{array}{l}\text { Wild nuts } \\
\text { [autumn] }\end{array}$ & $\begin{array}{l}\text { Mountains; } \\
\text { water; } \\
\text { crags }\end{array}$ \\
\hline
\end{tabular}

and poetry. His approach to the world is reflected in the name he gave himself: Daigu, or "Great Fool" (Maloney \& Oshiro, 1992). Ryokan lived a life of wabizumai (solitary and simple living) in a one-room hut on Mount Kagami, visiting nearby villages and begging for his food in the Buddhist tradition (Maloney \& Oshiro, 1992). "His love of nature and life was legendary and endeared him to all he come into contact with" (Juniper, 2003: p. 157). According to Koren (2008: p. 22),

the self-imposed isolation and voluntary poverty of the hermit and ascetic 
[provides] opportunities for spiritual richness[, and] for the poetically inclined, this kind of life [fosters] an appreciation of the minor details of everyday life and insight into the beauty of the inconspicuous and overlooked aspects of nature.

Ryokan's poetry is simple, direct, and colloquial, and his poetry is inseparable from his life (Maloney \& Oshiro, 1992). His poetry is primarily centered around his daily activities, "and is noted for its simplicity of statement and emotional warmth" (Watson, 1996: p. 180; see also Maloney \& Oshiro, 1992). Saigyo (1118-1190) was a warrior who became a Zen monk and traveler-poet and who also lived alone for long periods. His long poetic journeys may have inspired both Basho and Jakuren (see Table 6).

Poems by Saigyo and Soseki are presented in Table 5, and are related by the strength of their wabi-sabi/Zen, particularly their references to being alone, loneliness, and isolation. Soseki (1275-1351) was a Zen monk and teacher, calligraphist, poet, and garden designer.

Poems by Saigyo, Jakuren, and Emperor Fushimi are presented in Table 6, and are related by their mountain settings and the strength of their wabi-sabil Zen, particularly their references to loneliness and silence. Jakuren (1139-1202) was a Zen priest and poet, and Emperor Fushimi (1265-1317) was the ninety-second emperor of Japan.

Poems by Saigyo and Kino Tomonori are presented in Table 7, and are related by their lighter spring tone. These poems are included to show the reader that not all Japanese poems with strong environmental themes are so melancholic. Kino Tomonori (850-904) was a tanka poet of the Heian court.

Table 5. Selected Poems by Saigyo and Soseki.

\begin{tabular}{|c|c|c|c|}
\hline Poems & Wabi-SabilZen Terms & Kigo & Additional Nature Terms \\
\hline $\begin{array}{l}\text { Deep in a ravine, } \\
\text { in a tree on the old farm, } \\
\text { a single dove sings out, searching for a friend, } \\
\text { lonely voice of the evening. } \\
\text { - Saigyo } \\
\text { (Hamill \& Seaton, 2004: p. 106) }\end{array}$ & $\begin{array}{l}\text { Deep; } \\
\text { old farm; } \\
\text { single; } \\
\text { searching; } \\
\text { lonely voice; } \\
\text { evening }\end{array}$ & [None] & $\begin{array}{l}\text { Ravine; } \\
\text { tree; } \\
\text { dove }\end{array}$ \\
\hline $\begin{array}{l}\text { Whom is it calling } \\
\text { in this high mountain village, } \\
\text { that lonely cuckoo? } \\
\text { When I came here, I came } \\
\text { alone, just wanting a life. } \\
\text {-Saigyo } \\
\text { (Hamill \& Seaton, 2004: p. 108) }\end{array}$ & $\begin{array}{l}\text { High mountain village; } \\
\text { lonely; } \\
\text { alone; } \\
\text { "just wanting a life" }\end{array}$ & $\begin{array}{l}\text { Cuckoo } \\
\text { [summer] }\end{array}$ & \\
\hline $\begin{array}{l}\text { If only people } \\
\text { would not come to visit me } \\
\text { in lonely mountains } \\
\text { where I have built my retreat } \\
\text { from the world's many trials. } \\
\text {-Soseki } \\
\text { (Hamill \& Seaton, 2004: p. 123) }\end{array}$ & $\begin{array}{l}\text { Lonely; } \\
\text { retreat; } \\
\text { "from the world's many trials" }\end{array}$ & [None] & Mountains \\
\hline
\end{tabular}


Table 6. Selected Poems by Saigyo, Jakuren, and Emperor Fushimi.

\begin{tabular}{|c|c|c|c|}
\hline Poems & Wabi-SabilZen Terms & Kigo & Additional Nature Terms \\
\hline $\begin{array}{l}\text { This loneliness is } \\
\text { not simply the result of } \\
\text { of autumn colors- } \\
\text { even mountain evergreens make } \\
\text { me feel like autumn evening. } \\
\text { - Saigyo } \\
\text { (Hamill \& Seaton, 2004: p. 112) }\end{array}$ & Loneliness & $\begin{array}{l}\text { Autumn colors; } \\
\text { autumn evening }\end{array}$ & Mountain evergreens \\
\hline $\begin{array}{l}\text { Call it loneliness, } \\
\text { that deep, beautiful color } \\
\text { no one can describe: } \\
\text { over these dark mountains, } \\
\text { the gathering autumn dusk. } \\
\text { - Jakuren } \\
\text { (Hamill \& Seaton, 2004: p. 114) }\end{array}$ & $\begin{array}{l}\text { Loneliness; } \\
\text { dark; } \\
\text { gathering autumn dusk }\end{array}$ & Autumn & Mountains \\
\hline $\begin{array}{l}\text { Only now I know } \\
\text { that power-greater than storms- } \\
\text { a heart-rending awe } \\
\text { silencing all the pines } \\
\text { at nightfall on the mountain. } \\
\text {-Emperor Fushima } \\
\text { (Hamill \& Seaton, 2004: p. 121) }\end{array}$ & $\begin{array}{l}\text { Silencing; } \\
\text { nightfall }\end{array}$ & [None] & $\begin{array}{l}\text { Storms; } \\
\text { pines; } \\
\text { mountain }\end{array}$ \\
\hline
\end{tabular}

Table 7. Selected Poems by Saigyo and Kino Tomonori.

\begin{tabular}{|c|c|c|c|}
\hline Poems & Wabi-SabilZen Terms & Season Identifiers & Additional Nature Terms \\
\hline $\begin{array}{l}\text { Along the trail's edge } \\
\text { beside a sparkling river } \\
\text { in the willow shade, } \\
\text { I lingered to take a nap- } \\
\text { linger, and I'm still here. } \\
\text { - Saigyo } \\
\text { (Hamill \& Seaton, 2004: p. } 108\end{array}$ & $\begin{array}{l}\text { Linger; } \\
\text { "I'm still here" }\end{array}$ & $\begin{array}{l}\text { Willow } \\
\text { [spring] }\end{array}$ & $\begin{array}{l}\text { Trail's edge; } \\
\text { sparkling river }\end{array}$ \\
\hline $\begin{array}{l}\text { Sunlight, so peaceful- } \\
\text { radiant on this spring day: } \\
\text { A heart not at rest- } \\
\text { ah, that the cherry petals } \\
\text { have to be scattered so soon! } \\
\text { - Kino Tomonori } \\
\text { (Kirkup, 1996: p. 19) }\end{array}$ & "Scattered so soon" & $\begin{array}{l}\text { Spring day; } \\
\text { cherry petals }\end{array}$ & Sunlight \\
\hline
\end{tabular}

The final group of poems, by Gozan, Basho, and Ryokan, are presented in Table 8, and are related by their strong circle-of-life wabi-sabi/Zen themes. Gozan (1717-1787) was a haiku poet, and the second poem, below, which reflects both the circle-of-life and the transience of its stages, is considered his jisei. In general, things in bud and things in decay (i.e. beginnings and endings) are more representative of wabi-sabi/Zen than things in full bloom because they better evoke this transience. 
Table 8. Selected Poems by Gozan, Basho, and Ryokan.

\begin{tabular}{|c|c|c|c|}
\hline Poems & Wabi-Sabi/Zen Terms & Kigo & Additional Nature Terms \\
\hline $\begin{array}{l}\text { Nothing in the cry } \\
\text { of cicadas suggests they } \\
\text { are about to die. } \\
\text { - Basho } \\
\text { (Hamill \& Seaton, 2004: p. 150) }\end{array}$ & "About to die" & $\begin{array}{l}\text { Cicada } \\
\text { [summer] }\end{array}$ & \\
\hline $\begin{array}{l}\text { What shall remain as my legacy? } \\
\text { The spring flowers, } \\
\text { the cuckoo in summer, } \\
\text { the autumn leaves. } \\
\text { - Ryokan } \\
\text { (Maloney \& Oshiro, 1992) }\end{array}$ & "What shall remain as my legacy" & $\begin{array}{l}\text { Spring; } \\
\text { cuckoo; } \\
\text { summer; } \\
\text { autumn }\end{array}$ & $\begin{array}{l}\text { Flowers; } \\
\text { leaves }\end{array}$ \\
\hline $\begin{array}{l}\text { The snow of yesterday } \\
\text { that fell like cherry blossoms } \\
\text { is water once again. } \\
\text {-Gozan } \\
\text { (Hoffman, 1996: p. 180) }\end{array}$ & $\begin{array}{l}\text { [Implicit concepts of circular existence and } \\
\text { transience] }\end{array}$ & $\begin{array}{l}\text { Cherry blossoms; } \\
\text { "snow of yesterday" } \\
\text { [spring] }\end{array}$ & Water \\
\hline
\end{tabular}

\section{Discussion}

These and many other traditional Japanese poems with strong environmental themes can be a useful tool for environmental education. The qualities of impermanence, humility, asymmetry, and imperfection emphasized in wabi-sabi and the quality of one-ness emphasized in Zen are diametrically opposed to the Western values of permanence, grandeur, symmetry, perfection, and distinction, and where Western culture finds ugliness and danger in nature, wabi-sabi and Zen find beauty and inspiration. "Wabi-sabi art...can put us back in touch with our non-dualistic perception" (Juniper, 2003: p. 25). Wabi-sabi, in particular, relates to modern environmental concerns through its association with minimal consumption, organic lifestyles, and respect for nature which fosters a caring attitude toward it (Juniper, 2003).

Murphy (2014) made a strong case for Zen in understanding and addressing our environmental ills, particularly the intractable problem, or koan (paradoxical problem) of climate change the solution to which is unlikely to be found in the same technoscientific paradigm that created it. Western civilization has long defined itself in opposition to and measured itself by the ability of its science and technology to conquer nature, even when the same science and technology create even larger environmental problems (as in the case of climate change). "It is just this learned idea that we are separate from our environment that Zen says we need to unlearn" (Juniper, 2003: p. 24). Only relatively recently have many Westerners begun to seek a more conciliatory approach to nature, as reflected, for example, in the deep ecology movement which reflects aspects of Zen. Essential to the success of nurturing and growing this more enlightened perspective is communication with emotional appeal that creates a stronger personal connection and investment than the rational intellectualization so favored by Western culture. As noted by Stibbe (2012): 
Overall, the importance of the discourse of haiku is that, like a Zen koan, it uses language to encourage the reader to go beyond language, beyond the world of intellectual abstractions, and reconnect directly with the more-than-human world. The way it does this is to describe actual encounters with everyday nature, in straight present tense, using a minimal amount of metaphor and abstraction, placing poetic emphasis on individual animals and plants, representing them as agents of their own lives living according to their natures, with implicit assumptions of empathy and positive regard built into the discourse... By taking ordinary animals and plants, and giving them a prime position within a highly appreciated cultural art form, haiku give the message that they are important for themselves.

Barnhill (2004) saw Basho's poems as combining nature and the Japanese tradition associated with it, and saw his treatise on Basho's poems as appealing to both students of Japanese literature and religion as well as to naturalists and students of nature writing. In fact, "the last fifty years have seen increasing interest in Basho among scholars, poets, nature writers, and environmental philosophers" (Barnhill, 2004: p. ix). Educators have also recognized the power of Japanese poetry to develop awareness of and sensitivity to environmental issues (Kundell, 1973; Rowsey, 1979; Rillero, 1999; Rillero, Cleland, \& Conzelman, 1999; Wakan, 2003; Stibbe, 2012; Burrow, 2016). "The ultimate objective of environmental education is the production of an attitude that will enable the person to function in harmony with the environment... The writing of haiku is an experience that should aid in the formation of ecologically oriented attitudes" (Kundell, 1973: p. 48). In fact, "science and haiku share a focus on nature, employing keen observation and succinct description. Effective haiku writing depends upon directly experiencing nature" (Rillero, 1999: p. 345). This is because haiku encourage and record encounters with real animals and plants, rather than engage in over-intellectualized discussions of abstract categories and concepts (Stibbe, 2012). For these reasons, national and international government agencies (e.g. United States Environmental Protection Agency, 2012; United Nations Development Programme, 2017), non-governmental organizations (e.g. Oester \& Januchowski-Hartley, 2018; Global Development Research Center, 2018; Environmental Watch, 2014, noting that "haiku...are a simple and beautiful way to convey some of the most striking facts we are facing today"; Living on Earth, 2014), and institutions of higher education (e.g. Farber, 2013; University of Miami, 2018) have all created or hosted online haiku pages to facilitate their educational missions.

Of course, for use as an educational tool, much can and should be done to adapt the basic framework of Japanese poetry to be more applicable and relevant to different cultural and environmental contexts. For example, different cultures and/or ecosystems will likely have different kigo. It is worth noting that nature is omnipresent and can be found even in the largest and most densely populated 
cities (Cronon, 1995), and urbanites can benefit as much or more from the increased awareness of nature provided by these poems.

\section{Conclusion}

The wabi-sabi and Zen perspectives in Japanese poetry with particularly strong nature themes provide a vehicle for educative communication with emotional appeal that erases the dualism and materialism created by self-interest and egocentric reason, and facilitates reconnection with nature (Juniper, 2003; Stibbe, 2012). As a result, the Japanese poems discussed above and many others articulate and strengthen what increasing numbers of Westerners intuitively feel about the natural environment and their desire to, in the words of Basho, "submit to nature, return to nature" (Higginson, 1996).

\section{Acknowledgements}

The authors are grateful to Hovey Williams LLP for its generous support of science and innovation.

\section{Conflicts of Interest}

The authors declare no conflicts of interest regarding the publication of this paper.

\section{References}

Addiss, S. (2012). The Art of Haiku: Its History through Poems and Paintings by Japanese Masters. Boston, MA: Shambhala.

Barnhill, D. L. (2004). Basho's Haiku: Selected Poems of Matsuo Basho. Albany, NY: State University of New York Press.

Blyth, R. H. (1949). Haiku. Tokyo: Hokuseido.

Burrow, L. E. (2016). Seeing Science in Haiku: Primary Students Explore Connections between Science and Writing. Science and Children, 54, 58-64.

Cleary, T. (1998). Teachings of Zen. Boston, MA: Shambhala.

Cohen, W. H. (1972). To Walk in Seasons: An Introduction to Haiku. Rutland, VT: Charles E. Tuttle Company.

Cronon, W. (1995). The Trouble with Wilderness; or, Getting Back to the Wrong Nature. In W. Cronon (Ed.), Uncommon Ground: Rethinking the Human Place in Nature (pp. 69-90). New York: W. W. Norton.

Environmental Watch (2014). A Beautiful Way to Talk about Climate Change. http://www.environmental-watch.com/2014/01/10/beautiful-way-talk-climate-change$\underline{\text { haiku }}$

Farber, D. (2013). Environmental Haiku for the Summer. https://blogs.berkeley.edu/2013/07/03/environmental-haiku-for-summer/

Global Development Research Center (2018). Haiku on Ecology and the Environment. http://www.gdrc.org/sustdev/haiku.html

Greve, G. (2017). World Kigo Database. http://www.worldkigodatabase.blogspot.com

Hamill, S., \& Seaton, J. P. (2004). The Poetry of Zen. Boston, MA: Shambhala. 
Higginson, W. J. (1996). The Haiku Seasons. Poetry of the Natural World. New York: Kodansha International.

Hoffman, Y. (1996). Japanese Death Poems. Written by Zen Monks and Haiku Poets on the Verge of Death. Rutland, VT: Charles E. Tuttle Co.

Juniper, A. (2003). Wabi Sabi: The Japanese Art of Impermanence. North Clarendon, VT: Tuttle Publishing.

Kirkup, J. (1996). A Book of Tanka. Salzburg: University of Salzburg.

Koren, L. (2008). Wabi-Sabi for Artists, Designers, Poets, \& Philosophers. Point Reyes, CA: Imperfect Publishing.

Koren, L. (2015). Wabi-Sabi: Further Thoughts. Point Reyes, CA: Imperfect Publishing.

Kundell, J. E. (1973). Haiku in Environmental Education. The Science Teacher, 40, 48.

Living on Earth (2014). Earth Day Haiku. http://www.loe.org/shows/segments.html?programID=14-P13-00017\&segmentID=7

Loori, J. D. (2007). Teachings of the Earth: Zen and the Environment. Boston, MA: Shambhala Publications.

Maloney, D., \& Oshiro, H. (1992). Between the Floating Mist: Poems of Ryokan. Buffalo, NY: Springhouse Editions.

Murphy, S. (2014). Minding the Earth, Mending the World: Zen and the Art of Planetary Crisis. Berkeley, CA: Counterpoint.

Oester, S., \& Januchowski-Hartley, S. (2018). Conservation Scientists Come Together to Haiku.

http://www.conbio.org/publications/scb-news-blog/conservation-scientists-come-toget her-to-haiku

Richie, D. (2007). A Tractate on Japanese Aesthetics. Berkeley, CA: Stone Bridge Press.

Rillero, P. (1999). Haiku and Science-Observing, Reflecting, and Writing about Nature. Journal of College Science Teaching, 28, 345-347.

Rillero, P., Cleland, J. V., \& Conzelman, K. A. (1999). The Nature of Haiku. Science and Children, 37, 16.

Rowsey, R. E. (1979). Haiku: Touching Nature through Poetry. The Science Teacher, 46, 36.

Stibbe, A. (2012). Animals Erased: Discourse, Ecology, and Reconnection with the Natural World. Middletown, CT: Wesleyan University Press.

Suzuki, D. T. (1959). Zen and Japanese Culture. New York: Pantheon Books.

Suzuki, D. T. (1960). Manual of Zen Buddhism. New York: Grove Press.

Suzuki, D. T. (1964). An Introduction to Zen Buddhism. New York: Grove Weidenfield.

Takashina, S., \& Treyvaud, M. (2018). The Japanese Sense of Beauty. Tokyo: Publishing Industry Foundation for Culture.

Takiguchi, S. (2005). A Contrarian View of Basho's Frog. World Haiku Review, 5.

Teiji, I., Ikko, T., \& Tsune, S. (1993). Wabi, Sabi, Suki: The Essence of Japanese Beauty. Tokyo: Mazda Motor Corporation.

United Nations Development Programme (2017). Inspired by Nature: Celebrating Biodiversity with Haikus.

http://www.undp.org/content/undp/en/home/librarypage/environment-energy/ecosyste ms_and_biodiversity/inspired-by-nature--celebrating-biodiversity-with-haikus.html

United States Environmental Protection Agency (2012). Environmental Haikus. http://www.gdrc.org/sustdev/haiku.html 
University of Miami (2018). Your Haiku to the Environment. http://climate.miami.edu/your-haiku-to-the-environment/

Wakan, N. B. (2003). Haiku-Writing: Learning from the Pine. Green Teacher, 72, 13.

Watson, B. (1996). Ryokan. The Literary Review, 39, 180-187.

Zheng, J. (2014). Rereading Basho's Frog Haiku: Its Stylistic Features. Japan Studies Association Journal, 12, 1-11. 